\title{
22 C like clever and cycle
}

\author{
Without a smart and systematic \\ conception of the metal industry, \\ product labelling and an indicator \\ system, nothing will happen
}

\author{
Kathrin Greiff, Florian Fiesinger, Christa Liedtke, \\ and Martin Faulstich
}

\section{Introduction}

Metals are essential for a wide range of applications and technologies. These include vehicle construction, information and communication technology, renewable energy production and medical technology (MarscheiderWeidemann et al. 2016). Their availability is of the utmost importance for our society, but this is not guaranteed in the long term. Based on the number of elements in the periodic table, most metals, especially rare earths, are not recovered after use and have recycling rates close to 0\% (UNEP 2011). Irrespective of existing static ranges the metal content in the earth is finite. Even if metals such as indium, zinc or zirconium theoretically have static resource ranges of more than 100 years, the limitedness of the earth tells us something different - the elements cannot be multiplied, even if we continuously discover new sources. At present, it is not scarcity that seems to be the problem, but rather the economic availability of primary and secondary sources. This economic availability initially leads to bottlenecks and economic restrictions in the existing growth course. Germany is in a weak position here, as it has no raw material sources. It must, therefore, deal intelligently with its raw materials and budget them if it wants to remain competitive. In the process of the raw material transition, there is no alternative but to meet the long-term demand for metals mostly from secondary raw materials.

In addition to the physical scarcity, the planetary boundaries in the handling of metals must be ensured (Steffen et al. 2015). Specifically, the limit of the remaining $\mathrm{CO}_{2}$ budget of $420 \mathrm{GtCO}_{2}$ for the $1.5^{\circ}$ target of the IPCC must be fulfilled (IPCC 2018). The global energy consumption of primary metal production is responsible for $7-8 \%$ of the global energy expenditure (UNEP 2013). The most effective way to reduce $\mathrm{CO}_{2}$ emissions and other environmental impacts as land-use change, biodiversity loss or toxic emissions in metallurgy is secondary production. In the case of aluminium, cumulative energy consumption (CED) is reduced by 80 up to $95 \%$ and $\mathrm{CO}_{2}$ emissions by $80 \%$ compared to primary production. This balance is similar for other metals (Frischenschlager et al. 2010; Steger et al. 2019). 
The earth's capacity to absorb greenhouse gases is ultimately a critical limiting factor in the handling of metals. The fact that the demand for metals far exceeds their secondary production is extremely problematic at this point (Wilts \& von Gries 2017). Nevertheless, metals are crucial for climate protection and energy system transformation (Teubler, Kiefer \& Liedtke 2018). Examples are the rare earth metal neodymium used in high-performance permanent magnets in wind turbines, the alkali metal lithium as the most important component in batteries, or the metal tellurium used in thin-film solar cells to generate solar power (Marscheider-Weidemann et al. 2016). It is therefore essential to promote the aspects of resource efficiency and to strengthen the critical role of metals in national and European policy programs. Next to a global solution, a European solo effort with predominantly marketbased instruments and the effects of committed behaviour by civil society in the European Union (EU), show that the EU can make a considerable contribution to sustainable development on its own (Distelkamp, Meyer \& Moghayer 2015). Thus, a comprehensive approach is needed for sustainable metal management in the sense of a circular economy on the European level fostering sustainable production and consumption pathways. But, this need and the special role of metals are not seen in the current debate about resources in society and politics. Due to the fact that in public perception, metallic raw materials are often discussed as less urgent than energy or polymer raw materials, this article aims to highlight the critical role of metals.

Further, the objective of this contribution is to show which prerequisites exist for the development and establishment of a holistic metal management and where political strategies have to start. Challenges needed to be overcome to achieve such a holistic metal strategy and management are highlighted. In particular, the role of the metal industry, circular product design and labelling and corresponding indicator systems is examined. In addition, the special role of digitalisation is being worked out. Finally, conclusions are drawn and shown which aspects have to be considered for a holistic metal strategy and management.

\section{Requirements for circular management}

\section{The role of the metal industry}

Metallic raw materials are of strategic importance for the highly specialised German economy, especially for the expansion of renewable energies, in the field of (electric) mobility and construction or housing. However, Germany has no economically exploitable metal deposits. Metal ores and concentrates are fully imported. In the criticality study undertaken by the European Commission in 2017, metals used in future technologies such as solar cells, fibre-optic cables and magnets for wind turbines were classified as particularly critical (European Commission 2017). For these metals, suitable recovery processes must be developed which, on the one hand, ensure the necessary purity levels and, on 


\section{Kathrin Greiff et al.}

the other hand, are economically viable (Fröhlich et al. 2017). For this purpose, the value-added chains of primary production in Germany and Europe must be maintained, since they are simultaneously used for secondary production. It is a matter of maintaining economic profitability as well as the basic supply of our society with metallic raw materials.

The metal industry is a key industry in Germany. It is divided into the steel and non-ferrous metal sectors. In the steel industry in Germany, 42.1 million tons, steel scrap accounted for 43\%, were produced in 2016 by $85,000 \mathrm{em}-$ ployees in 68 companies and generated a turnover of 35.1 billion euros (Wirtschaftsvereinigung Stahl 2018). The products are mainly used in the construction industry, in the automotive industry and for mechanical engineering. Products from the non-ferrous metal industry, on the other hand, are used in high-tech applications in the aerospace, automotive, chemical and electrical industries. In 2017, the non-ferrous metals industry employed 108,000 people in 655 companies and generated a turnover of 51.3 billion euros. Of the 2.634 million tonnes of crude base metal produced in 2017, 52\% was made from secondary sources (Wirtschaftsvereinigung Metalle 2018).

This strength in the metal industry is an opportunity to further expand the leading role in the secondary production of metals. The demand for metals will continue to rise in future (Elshkaki et al. 2018). Drivers are countries such as China or India, which want to catch up with the standard of living of industrial countries. Secondary production in Germany and Europe can make a major contribution to meeting the future demand for metals, provided that existing metallurgical structures are maintained or further expanded. Particularly in the case of functional technology elements or materials, new metallurgical structures must be investigated and established for a functioning secondary raw materials economy or preferably circular economy (Reuter et al. 2019). Besides, research activities should also be intensified with regard to accompanying modelling, especially in relation to the modelling of availability and losses.

\section{The role of eco-design}

To integrate sustainable development into European environmental legislation, the White Paper on Integrated Product Policy (IPP) was released in 2003. The focus of environmental policy was on the entire life cycle of products and manufacturers were required to assume greater product responsibility for their products placed on the market. Manufacturers know the exact material composition of their products and know best how they can be dismantled in the most efficient way. For this reason, binding take-back and recycling obligations must be introduced for product manufacturers. These represent the optimal way to increase collection and recycling quotas. Various policy instruments exist at European level to implement such objectives. Those instruments protect consumers and the environment from possible negative impacts. Products in the European market should thus become 
more sustainable. These policy instruments can be divided into 'push and pull' measures. The 'push' instruments set minimum standards that must be met for a product to be approved for the European market at all (exclusion of nonsustainable products from the market). The 'pull' instruments are voluntary requirements that go beyond the minimum standards, for example, product labels (European Commission 2019).

Another way to increase the product responsibility for manufactures is the use of service concepts and business models such as leasing which are already implemented in the product development or design phase. The so-called sharing economy leads to reduced consumption of raw materials by aligning the interests of manufacturers and users (Liedtke, Buhl \& Ameli 2013b). A carsharing vehicle can substitute up to 20 private cars according to a study by the German CarSharing Association (bcs 2016) and saves around 11,440 kg of steel, $190 \mathrm{~kg}$ of cast iron and $1,710 \mathrm{~kg}$ of aluminium per car-sharing vehicle. However, leasing models must be evaluated more strongly, as otherwise, the design of services could lead to problem shifts and rebound effects (Clausen, Bowry \& Bienge 2017). To avoid increased resource usage in production and consumption, such complex value creation models should be tested step by step in real-world laboratories and 'LivingLabs' (Schneidewind 2014, Liedtke et al. 2015). In this way, the effects as mentioned above and objectives can be modelled for implementation in the circular economy and made tangible for policymakers.

$80 \%$ of all product-related environmental impacts are determined in the design phase (Tischner \& Moser 2015). The product design actively influences the criteria longevity, reparability and recyclability of a product and contributes significantly to the conservation of resources of metallic raw materials (Liedtke, Buhl \& Ameli 2013a; Liedtke 2018). As the European Environment Agency defines, 'Eco-Design delivers products made with fewer resources, using recycled and renewable resources and avoiding hazardous materials, as well as with components that are longer lasting and easier to maintain, repair, upgrade and recycle' (European Environment Agency 2016: 18). However, the implementation of a design suitable for recycling is associated with certain challenges. The complexity of products in terms of the quantity of raw materials used has increased rapidly over the last 100 years. For example, every technically usable element of the periodic table is used by now. This is symbolised by the increase in the metals required for energy generation technologies as shown by Zepf et al. (2014). For example, modern wind turbines require the entire range of rare earths for high-performance permanent magnets (Marscheider-Weidemann et al. 2016).

With this, the recovery of functional metals becomes very complex or even impossible, due to complex metal interconnections and thus irreversible losses that are 'an inevitable part of industrial circular economy' or rather recycling processes (Reuter et al. 2019: 10.5; Reuter \& Van Schaik 2016). These dissipative mechanisms remove metals from the material cycle in a way and on a scale that makes it thermodynamically or economically impossible to 
recover them. Therefore, it is crucial to understand the functioning of dissipation to prevent it.

A high dissipation rate can be found in particular in the metals classified as critical by the European Commission. These metals are increasingly used in information and communication technology (ICT) or rather for digitalisation (see further below). Losses can be attributed to the use of a variety of metals in complex combinations. Existing recycling schemes are unable to cope with the increasing complexity of these primarily electrical and electronic products and [e-]wastes. Prime examples are smartphones, in which about 56 metals are used (Bookhagen et al. 2018). Most of the metals are not recovered at all and have recycling rates below 1\% (UNEP 2011). Accordingly, relevant material research on topics such as corrosion, abrasion or the entropy of metals must be increasingly promoted in order to better understand the mechanisms of dissipative losses. In order to be able to map possible losses due to material composition and interactions, modelling at the product level is necessary, which must be incorporated directly into the design process. For this, Reuter et al. (2019) presented a simulation approach for end of life processes on the product level. With this concept, potentials for a circular economy with high significance can be derived via a bottom-up approach.

However, recycling processes also of basic metals always lead to material loss. European Environment Agency showed for the case of aluminium that 'even in a very circular system only $16 \%$ of the aluminium remains in the cycle after 10 years' (European Environment Agency 2017: 25). According to this, recycling should not be the only priority, but the principles of modularity should be given greater consideration and thus the inner loops of circular economy to increase product and material lifetimes (European Environment Agency 2017). Many products contain a large number of different metals which must be used as efficiently as possible. Modularity makes it possible to replace individual defective components in products, thus extending their useful lifetime. A modular design also contributes to better disassembly and separation of the components and higher recovery rates of the metals contained when entering the recycling process (Reuter, Van Schaik \& Ballester 2018). Schoch (2019) showed in a case study of mobile phone screens, that design for disassembly could lead to standardisation in the design process. This standardisation enables the exchange and further use of modules so that materials can be kept longer in the economic cycle and thus dissipation of recycling processes is prevented or postponed.

To accelerate the use of recyclable design, it makes sense to introduce binding design guidelines as required in the Eco Design Directive (Directive 2009; Greiff \& Liedtke 2019) and incentives for a 'design for recycling' and recovery should be promoted. Furthermore, material databases should be set up, which can be used in the design process. For example, in Switzerland and Germany, networks were formed which want to build up and expand a material database in such a way that construction and design based on key figures of a circular economy are possible (www.materialarchiv.ch). 
As described above, the requirements of the Eco Design Directive as a push instrument are representing a minimum standard. To be able to influence products beyond this minimum, a product labelling system should be set up and established with the aim of strengthening the comparability of products among themselves - as already proposed by the Resource Commission at the Federal Environment Agency in Germany (Ressourcenkommission am Umweltbundesamt 2017). This state-installed unit for the supervision of mandatory labelling of products in the area of resource efficiency and recyclability has the task of collecting, testing and monitoring certain information to be supplied by companies for products that are placed on the market in Germany or Europe. It verifies whether the product-related information supplied by the manufacturers or distributors complies with the requirements of the labelling unit (Ressourcenkommission am Umweltbundesamt 2017).

\section{The role of Indicators}

For measuring the effectiveness of a circular economy in general and particularly in the metals sector, a set of expressive indicators for monitoring the different CE strategies and also for developing benchmarks is needed. There is no comprehensive approach in place for measuring the circular economy, yet (Potting et al. 2017; Pauliuk 2018; Saidani et al. 2019). Ellen MacArthur Foundation identified the four assessment categories for the circular economy: 'resource productivity, circular activities, waste generation, energy and GHG emissions' (Ellen MacArthur Foundation 2015). Considering resource consumption and raw material productivity, the quantity of resources that remains in the economic cycle through recycling is an essential parameter for assessing resource use in the context of the circular economy. By now, most recycling rates in Europe are based on input streams from recovery plants. With this calculation method, the effectiveness of the circular economy cannot be measured in any way. Even if the calculation method based on output flows is to be standardised in future by an initiative of the European Commission, this indicator reflects the quality of the collection and recycling infrastructure, but not how much recycled material is actually returned to the economic cycle. The European Commission has developed an indicator framework to establish monitoring for the circular economy beyond this indicator on macro-level (European Commission 2018). Among others, it is proposed to use this framework to map the proportion of recycled material that is returned to the production process. This framework thus meets the requirement for a substitution rate, as demanded by Resource Commission at the Federal Environment Agency in Germany (Ressourcenkomission am Umweltbundesamt 2019).

At the European level, an attempt is made to map this indicator, called EOL-RIR (End-of-life recycling input rates) at the element level and CMU (Circular Material Use rate) at the European level, on the basis of existing statistics. However, for the CMU the same data basis is used for the calculation 
of recycling quotas. As a result, the significance is not yet sufficiently valid, but the methodological approach is the right way forward. An improvement in the data situation should nevertheless be sought. Nevertheless, the requirements of the Resource Commission at the Federal Environment Agency go beyond this framework. The returned material should not only be identified on element level and European or national level but also derived at the product level. Especially in the context of metals, it is essential to present and ensure differentiation at the functional level.

This approach to a functional substitution rate can only be part of a comprehensive set of indicators against the background of the diverse CE strategies. As Pauliuk (2018), for example, shows, a large number of indicators are currently being discussed at the product and company level as well as at the macro level, which can be used to measure circularity (see also Bringezu \& Bleischwitz 2009; Liedtke et al. 2014). In the case of metals, however, the introduction of a functional substitution rate would be an essential first step. This could also show the actual loss of certain functional materials or the positive effects of circular economy strategies.

\section{Specific role: Digitalisation}

In the case of metals, digitalisation plays a special role. On the one hand, digitalisation with the corresponding technological infrastructure generates a high demand for metals, which is also encouraged by rapid innovation cycles. The technologies used are thus an outstanding example of complex products. For example, German data centres contain neodymium with a quantity of about 52 t $\mathrm{Nd}_{2} \mathrm{O}_{3}$ equivalents (calculations based on data from Stobbe et al. 2015). As already described above, however, the quantities per technical unit are very low, the proportion for a hard disk is about $0.72 \%$ neodymium (Stobbe et al. 2015).

On the other hand, the question arises how digitalisation can make a constructive contribution to comprehensive metal management and recycling of metals. Digitalisation is leading to fundamental changes in our society. It enables new forms of economic activity through innovative business models and increased efficiency in processes. These positive effects should be seen as an opportunity for the metal industry to further advance the recyclability of metals.

According to the Wuppertal Institute, a lack of information about the nature, quality, quantity and availability of secondary material is the primary barrier. This lack of information tempts companies to hold on to primary materials instead of using recycled materials (Wilts \& Berg 2017). The digital transformation offers a number of possibilities to counteract the lack of information. The development of a digital, automated market and logistics platform between supply and recycling companies could provide a crosscompany sales area for secondary metals. Such digital market and platform would reduce search and transaction costs and strengthen the competitiveness 
of secondary raw materials. The use of the block chain technology could prevent data manipulation and ensure the reliability of the specified product information. Cascade benefits between the companies could also be organised directly in the sense of the above-mentioned material logistics. In addition, eliminating the lack of information, digitalisation offers further opportunities to make the recycling of metals more efficient. By using sensor technology, conclusions can be drawn beforehand about the composition of metal scrap. Based on these results, optimal process routes could be determined in real-time based on data analysis applications. Data availability and processing, e.g. through the use of artificial intelligence, must be used to determine and control material flows more precisely. By modelling and simulating the entire value chain of metallurgy, predictions could be made about recycling rates and qualities (Reuter et al. 2019; Reuter 2016). These predictions would make it possible to detect unintended developments at an early stage and take corrective measures accordingly. However, it should be noted that not all companies have the same possibilities to deal with digitalisation issues. In particular, small and medium-sized enterprises do not have the capacity to make high investments and deal with the associated risks. For these companies, a special support from the state should be considered.

\section{Conclusion}

Our high-tech society uses an increasing number of metals. These are used in highly complex products and in very low concentrations in relation to functional metals. A circular use of recycling is further complicated apart from the unavoidable and also dissipative losses of such a process. As part of the overall objective of achieving a sustainable society and economy, the aim must be to reduce these losses to a minimum. The sustainable use of metals is a prerequisite for a sustainable industrial society. For this, comprehensive, resource-efficient metal management which is based on the principles of the circular economy must be developed and established. Due to the fact that in the public perception metallic raw materials are often discussed as less urgent than energy or polymer raw materials, this article highlighted the critical role of metals. As pointed out in this contribution different fields play a crucial role in such systematic metal management: the metal industry, eco-design, comprehensive monitoring via indicators and particularly the role of digitalisation for the support of the previous aspects as well as a driver of metal use. These areas were examined in more detail for the implementation of metal management in the context of a circular economy.

In summary, it was shown that the ferrous and non-ferrous industries are essential pillars of the German economy. They are necessary to supply the German industry with basic materials which are used in many sectors such as the construction sector, the automotive sector or the electronics industry. It is essential that the infrastructure of the primary metal production in Germany and Europe are preserved in order to use them for secondary metal production 
in the future. In addition, the important role of eco-design in the sustainable use of metals was highlighted. Since $80 \%$ of all product-related environmental impacts are determined in the design phase, it is important to integrate topics such as resource efficiency, circularity, reuse, modularity, durability and reparability in this phase already. Only in this way, the impact of dissipation can be counteracted in the best way possible. To monitor the progress of change towards a more sustainable economy, an indicator, such as the substitution rate, is needed. The substitution rate is intended to relate the secondary raw materials employed to the total amount of material used. It can also be used to derive specifications at the product level, which in turn are used in eco-design. Digitalisation can play a decisive role here, especially for the processing of the data required.

As shown in this contribution, there are numerous approaches for the development of functional metal management, but there is still a high research need for a holistic implementation. The main aspects are:

- We need an advanced and flexible metallurgical infrastructure - particularly in the case of functional technology materials, new metallurgical structures and logistics systems must be investigated and established.

- We need eco-design standardisation and labelling on product level regarding circularity aspects as recyclability as well as recycling content.

- We need a strong monitoring system that includes a holistic set of indicators, starting with the implementation of a functional substitution rate.

- We must further develop digital techniques and use them to model circular product systems and, thus, holistic metal management.

In this discussion, the product level is identified as a critical starting point. Thus, these aspects and conclusions can be arranged along with the steps of a general product life cycle as shown in Table 22.1, to demonstrate which measures should be addressed at which life cycle stages (according to Greiff \& Faulstich 2018). A bottom-up approach seems to be the best option for metal management at political and industrial level and should be pursued further. Overall, it can be concluded that there will be no circular use of metals without the use of virgin metal. But today we are still a long way from an optimal state and are wasting and, above all, losing a large part of the raw materials that are important to us and which we will never be able to recover in this way. That is why the role of metals at all levels should be given particular importance.
Abbreviations
CE circular economy
CEC cumulative energy consumption
$\mathrm{CMU}$ circular material use rate
$\mathrm{CO}_{2}$ carbon dioxide 
Table 22.1 Aspects for a resource-efficient metal management according to products life cycle steps

\begin{tabular}{ll}
\hline Life cycle step & Aspects of resource-efficient metal management \\
\hline $\begin{array}{c}\text { Design for circularity } \\
\text { and sustainability }\end{array}$ & $\begin{array}{l}\text { Optimisation of product design } \\
\text { Focus on service design and user needs } \\
\text { (target group and benefit specification) } \\
\text { Integration of indicators for circularity in the design and } \\
\text { development process: focus on longevity, reparability and } \\
\text { recyclability using modelling or simulation tools } \\
\text { Focus on product-service systems combined with new business } \\
\text { models } \\
\text { Cooperation with all further life cycle stages } \\
\text { Concentrations of useful materials will decrease while the } \\
\text { environmental impact will increase } \\
\text { Resource efficiency can be improved by mining fewer raw } \\
\text { materials } \\
\text { Technically optimisation of production process within } \\
\text { thermodynamic equilibriums } \\
\text { Noticeable increases in efficiency by substituting materials } \\
\text { Closing and decreasing internal material loops along the life cycle } \\
\text { or value chain } \\
\text { Optimisation of production processes } \\
\text { Material efficiency through Remanufacturing or Refurbishment } \\
\text { Legal requirements for the content of recycled materials } \\
\text { Extension of service life through technical and design aspects or } \\
\text { leasing systems } \\
\text { Use of reparable and recyclable products } \\
\text { A shift in demand patterns towards consumption of less material- } \\
\text { intensive goods or services via product information and } \\
\text { labelling } \\
\text { Monitoring of EoL management success by expressive indicators, } \\
\text { implementation of standards } \\
\text { High collection and separation rates by optimisation of } \\
\text { infrastructure } \\
\text { Consideration and cooperation with product development or } \\
\text { design phase }\end{array}$ \\
\hline
\end{tabular}

$\begin{array}{ll}\text { EoL } & \begin{array}{l}\text { end of life } \\ \text { end of life recycling input rate } \\ \text { EOL-RIR } \\ \text { EU }\end{array} \\ \text { EHropean Union } \\ \text { greenhouse gas } \\ \text { Gt } & \text { gigatonnes } \\ \text { IPCC } & \text { International Panel on Climate Change } \\ \text { IPP } & \text { Integrated Product Policy } \\ \text { Nd2O3 } & \text { neodymium (III) oxide } \\ t & \text { tonnes } \\ \text { UNEP } & \text { United Nations Environmental Programme }\end{array}$




\section{Kathrin Greiff et al.}

\section{References}

bcs (2016). Neue bcs-Studie: Mehr Platz zum Leben - wie CarSharing Städte entlastet. CarSharing fact sheet Nr. 2. Available at: http://carsharing.de/sites/default/files/ uploads/bcs_factsheet_nr.2_0.pdf. (Accessed: 5 June 2019).

Bookhagen, B. et al. (2018). 'Rohstoffverbrauch von Smartphones', In Thiel, S., ThoméKozmiensky, E., and Goldmann, D. (eds). Recycling und Rohstoffe - Band 11, pp. 519-532, TK Verlag Karl Thomé-Kozmiensky.

Bringezu, S. and Bleischwitz, R. (2009). Sustainable Resource Management: Global Trends, Visions and Policies. Sheffield, UK: Greenleaf.

Clausen, J., Bowry, J. and Bienge, K. (2017). Five Shades of Sharing Eine Szenariogeschichte Rund Um Die Haken Und Ösen Der Sharing Economy. Berlin: Borderstep Institut. www.borderstep. de/wp-content/uploads/2017/08/NsB-Ress_5-Shades-7.pdf. (Accessed: 5 June 2019).

Directive (2009). 'Directive 2009/125/EC of the European Parliament and of the Council of 21 October 2009 Establishing a Framework for the Setting of Ecodesign Requirements for Energy-Related Products', Official Journal of the European Communities.

Distelkamp, M., Meyer, B. and Moghayer, S. (2015). 'Report about Integrated Scenario Interpretation. Deliverable 3.7a of the POLFREE project'. Available at: www.ucl.ac.uk/ polfree/publications/publications-2014/report-d37c.pdf (Accessed: 22 August 2019).

Ellen MacArthur Foundation (2015). Circularity Indicators: An Approach to Measuring Circularity Project Overview. Ellen MayArthur Foundation. Available at: www. ellenmacarthurfoundation.org/assets/downloads/insight/Circularity-Indicators_ProjectOverview_May2015.pdf (Accessed: 14 February 2019).

Elshkaki, A. et al. (2018). 'Resource Demand Scenarios for the Major Metals', Environmental Science and Technology, 52(5), pp. 2491-2497. doi: 10.1021/acs.est.7b05154.

European Commission (2017). Study on the Review of the List of Critical Raw Materials. Criticality Assessments. European Commission. Available at: http://hytechcycling.eu/ wp-content/uploads/Study-on-the-review-of-the-list-of-Critical-Raw-Materials.pdf (Accessed: 20 March 2019).

European Commission (2018). Measuring Progress towards Circular Economy in the European Union - Key Indicators for a Monitoring Framework. European Commission. Available at: http://ec.europa.eu/environment/circular-economy/pdf/monitoring-framework_staffworking-document.pdf (Accessed: 24 January 2019).

European Commission (2019). Commission Staff Working Document. Sustainable Products in a Circular Economy - Towards an EU Product Policy Framework contributing to the Circular Economy. European Commission. Available at: http://ec.europa.eu/environment/circulareconomy/pdf/sustainable_products_circular_economy.pdf (Accessed: 20 March 2019).

European Environment Agency (2016). Circular Economy in Europe Developing the Knowledge Base. Luxembourg: Publications Office of the European Union. Copenhagen: European Environment Agency. Available at: https://doi.org/10.2800/51444.

European Environment Agency (2017). Circular by Design - Products in the Circular Economy. EEA Report, No. 6/2017. Copenhagen: European Environment Agency.

Frischenschlager, H. et al. (2010). Klimarelevanz ausgewählter Recycling-Prozesse in Österreich.

Fröhlich, P. et al. (2017). 'Valuable Metals-Recovery Processes, Current Trends, and Recycling Strategies', Angewandte Chemie, 56(10), pp. 2544-2580. doi: 10.1002/anie. 201605417.

Greiff, K., and Faulstich, M. (2018). 'Resource Efficiency:Trends and Thepotential of Circular Economy'. CEC4Europe. www.cec4europe.eu/wp-content/uploads/2018/11/ 
Chapter-4.5_Ressource-Efficiency_Factbook-CEC4E_Faulstich_Greiff.pdf (Accessed: 6 February 2019).

Greiff, K. and Liedtke, C. (2019). 'Design für Kreislaufwirtschaft: Ausstieg aus der Wegwerfgesellschaft!', EntsorgaMagazin 2-8, 4.

IPCC (2018). Global Warming of $1.5^{\circ} \mathrm{C}$. An IPCC Special Report on the Impacts of Global Warming of $1.5^{\circ} \mathrm{C}$ above Pre-industrial Levels and Related Global Greenhouse Gas Emission Pathways, in the Context of Strengthening the Global Response to the Threat of Climate Change. Edited by V. Masson-Delmotte et al. doi: 10.1017/CBO9781107415324.

Liedtke, C. (2018). Design for Sustainability. A UNA-UK online publication. Available at: www.sustainablegoals.org.uk/design-for-sustainability/ (Accessed: 6 May 2019).

Liedtke, C., Buhl, J. and Ameli, N. (2013a). 'Designing Value through Less by Integrating Sustainability Strategies into Lifestyles', International Journal of Sustainable Design, 2(2), p. 167. doi: 10.1504/IJSDES.2013.057124.

Liedtke, C., Buhl, J. and Ameli, N. (2013b). 'Microfoundations for Sustainable Growth with Eco-Intelligent Product Service-Arrangements', Sustainability, 5(3), pp. 1141-1160. doi: $10.3390 /$ su5031141.

Liedtke, C. et al. (2014). 'Resource Use in the Production and Consumption System - The MIPS Approach'. Resources, 3(3), pp. 544-574.

Liedtke, C., Baedeker, C., Hasselkuß, M., Rohn, H. and Grinewitschus, V. (2015). 'UserIntegrated Innovation in Sustainable LivingLabs: An Experimental Infrastructure for Researching and Developing Sustainable Product Service Systems'. Journal of Cleaner Production, 97, 106-116. https://doi.org/10.1016/j.jclepro.2014.04.070.

Marscheider-Weidemann, F. et al. (2016). Rohstoffe für Zukunftstechnologien 2016, DERA Rohstoffinformationen 28. Deutsche Rohstoffagentur (DERA) in der Bundesanstalt für Geowissenschaften und Rohstoffe (BGR). Berlin.

Pauliuk, S. (2018). 'Critical Appraisal of the Circular Economy Standard BS 8001:2017 and a Dashboard of Quantitative System Indicators for its Implementation in Organizations', Resources, Conservation and Recycling, 129, pp. 81-92. https://doi.org/10.1016/j. resconrec.2017.10.019.

Potting, J. et al. (2017). 'Circular Economy: Measuring Innovation in the Product Chain. Policy Report'. PBL Netherlands Environmental Assessment Agency, The Hague. Available at: www.pbl.nl/sites/default/files/cms/publicaties/pbl-2016-circular-economymeasuring-innovation-in-product-chains-2544.pdf (Accessed: 6 February 2019).

Ressourcenkomission am Umweltbundesamt (2017). 'Position der Ressourcenkommission am umweltbundesamt. Produktkennzeichnungsstelle zur Förderung der Ressourceneffizienz und Kreislauffähigkeit von Produkten'. Umweltbundesamt (UBA). Available at: www. umweltbundesamt.de/sites/default/files/medien/1968/publikationen/kru_produktkennzeichnungsstelle.pdf.

Ressourcenkommission am Umweltbundesamt (2019). 'Position der Ressourcenkommission. Substitutionsquote: Ein realistischer Erfolgsmaßstab für die Kreislaufwirtschaft!' Umweltbundesamt (UBA). Available at: www.umweltbundesamt.de/sites/default/files/ medien/421/publikationen/190722_uba_kommp_substitutionsquote_bf.pdf (Accessed: 22 August 2019).

Reuter, M. A. (2016). 'Digitalizing the Circular Economy', Metallurgical and Materials Transactions B. Springer US, 47(6), pp. 3194-3220. doi: 10.1007/s11663-016-0735-5.

Reuter, M. A. et al. (2019). 'Challenges of the Circular Economy: A Material, Metallurgical, and Product Design Perspective', Annual Review of Materials Research, 49(1), pp. 253-274. doi: 10.1146/annurev-matsci-070218-010057. 


\section{Kathrin Greiff et al.}

Reuter, M. A. and Van Schaik, A. (2016). 'Recycling Indices Visualizing the Performance of the Circular Economy', World of Metallurgy - Erzmetall, 69(August), p. 4.

Reuter, M. A., Van Schaik, A. and Ballester, M. (2018). 'Limits of the Circular Economy: Fairphone Modular Design Pushing the Limits', World Metall. - Erzmetall, 71(2), pp. 68-79. doi: 10.1016/j.neuron.2008.10.014.Destabilization.

Saidani, M. et al. (2019). 'A Taxonomy of Circular Economy Indicators', Journal of Cleaner Production, 207, pp. 542-559. https://doi.org/10.1016/j.jclepro.2018.10.014.

Schneidewind, U. (2014). 'Urbane Reallabore - ein Blick in die aktuelle Forschungswerkstatt', Pnd Online, 3, pp. 1-7.

Schoch, K. (2019). 'Normierung für Reuse und Recycling. Masterarbeit'. Burg Giebichenstein Kunsthochschule University of Art and Design.

Steffen, W. et al. (2015). 'Planetary Boundaries: Guiding Human Development on a Changing Planet', Science, 347(6223), pp. 1259855-1259855. doi: 10.1126/science.1259855.

Steger, S. et al. (2019). Stoffstromorientierte Ermittlung des Beitrags der Sekundärroh- stoffwirtschaft zur Schonung von Primärrohstoffen und Steigerung der Ressourcenproduktivität, Texte 34/2019. Umweltbundesamt.

Stobbe, L. et al. (2015). Entwicklung des IKT-bedingten Strombedarfs in Deutschland. Fraunhofer-Institut für Zuverlässigkeit und Mikrointegration (IZM). Berlin.

Teubler, J., Kiefer, S. and Liedtke, C. (2018). 'Metals for Fuels? The Raw Material Shift by Energy-Efficient Transport Systems in Europe’. Resources, 7(3), p. 49. doi: 10.3390/ resources7030049.

Tischner, U. and Moser, H. (2015). How to Ecodesign. Umweltbundesamt.

UNEP (2011). Recycling Rates of Metals: A Status Report. A Report of the Working Group on the Global Metal Flows to the International Resource Panel. Nairobi: United Nations Environment Programme.

UNEP (2013). Environmental Risks and Challenges of Anthropogenic Metals Flows and Cycles. Nairobi: United Nations Environment Programme.

Wilts, H. and Berg, H. (2017). Digitale Kreislaufwirtschaft - Die Digitale Transformation als Wegbereiter ressourcenschonender Stoffkreisläufe, in brief 04/2017.

Wilts, H. and von Gries, N. (2017). 'Der schwere Weg zur Kreislaufwirtschaft', GWP Gesellschaft. Wirtschaft. Politik, 66(1), pp. 23-28. doi: 10.3224/gwp.v66i1.02.

Wirtschaftsvereinigung Metalle (2018). Metallstatistik 2017. Available at: www.wvmetalle.de/ fileadmin/uploads/public/Metallstatistik/Metallstatistik_2017.pdf. (Accessed: 22 August 2019).

Wirtschaftsvereinigung Stahl. 'Fakten Zur Stahlindustrie in Deutschland 2017', 2018. Available at: www.stahl-online.de/wp-content/uploads/2017/12/Fakten_Stahlindustrie_ 2017_rz_web.pdf. (Accessed: 22 August 2019).

Zepf, V., A. Reller, C. Rennie, M. Ashfield, and J. Simmons (2014). Materials Critical to the Energy Industry. An Introduction. 2nd Edition. Augsburg: University of Augsburg. Available at: www.mrm.uni-augsburg.de/de/gruppen/reller/downloads/Materials_Handbook_Rev_ 2012.pdf (Accessed: 22 August 2019). 